\title{
Carbon and nitrogen stable isotope analysis on the diet of Jomon populations from two coastal regions of Japan
}

\section{$\operatorname{AUTHOR}(S)$ :}

Kusaka, Soichiro; Hyodo, Fujio; Yumoto, Takakazu; Nakatsukasa, Masato

\section{CITATION:}

Kusaka, Soichiro ...[et al]. Carbon and nitrogen stable isotope analysis on the diet of Jomon populations from two coastal regions of Japan. Journal of Archaeological Science 2010, 37(8): 1968-1977

\section{ISSUE DATE:}

2010-08

URL:

http://hdl.handle.net/2433/123312

\section{RIGHT:}

Copyright @ 2010 Elsevier; この論文は出版社版でありません。引用の 際には出版社版をご確認ご利用ください。; This is not the published version. Please cite only the published version. 
Carbon and nitrogen stable isotope analysis on the diet of Jomon populations from two coastal regions of Japan

Soichiro Kusaka $^{a^{*}}$, Fujio Hyodo ${ }^{b}$, Takakazu Yumoto ${ }^{c}$, and Masato Nakatsukasa ${ }^{a}$ Journal of Archaeological Science, 37 (2010) 1968-1977.

${ }^{a}$ Department of Zoology, Graduate School of Science, Kyoto University, Kyoto 606-8502, Japan

SoichiroKusaka:kusaka@anthro.zool.kyoto-u.ac.jp

Masato Nakatsukasa: nakatsuk@anthro.zool.kyoto-u.ac.jp

${ }^{\mathrm{b}}$ Research Core for Interdisciplinary Sciences, Okayama University, Okayama 700-8530, Japan

Fujio Hyodo:fhyodo@cc.okayama-u.ac.jp

${ }^{\mathrm{c}}$ Research Institute for Humanity and Nature, Kyoto 603-8047, Japan

Takakazu Yumoto: yumoto@chikyu.ac.jp

${ }^{*}$ Corresponding author.

Address: Laboratory of Physical Anthropology, 2-go-kan, Graduate School of Science, Kyoto University, Kitashirakawa-oiwake-cho, Sakyo-ku, Kyoto city, Kyoto 606-8502, Japan

Tel.: +81-75-753-4094; Fax: +81-75-753-4083

E-mail:kusaka@anthro.zool.kyoto-u.ac.jp 
Journal of Archaeological Science, 37 (2010) 1968-1977

\section{Abstract}

We report on a stable isotope paleodietary reconstruction of Jomon populations in Japan during the Middle to Final Jomon period (ca. 5000-2300 years BP), focusing on dietary differences within and among populations and between regions. Carbon and nitrogen isotope analysis was performed on human and faunal bone collagen from six coastal sites along the Inland Sea in the Sanyo (Ota, Funamoto, and Tsukumo) region and along Mikawa Bay and the Pacific Ocean in the Tokai (Kawaji, Yoshigo, and Inariyama) region. We found that carbon and nitrogen isotope ratios were positively correlated, indicating that the Jomon people consumed a mixed diet of marine (shellfish and marine fish $)$ and terrestrial $\left(\mathrm{C}_{3}\right.$ plants and terrestrial mammals $)$ protein. In the Ota samples $(n=25$, during the Middle Jomon period, 5000-4000 years BP), sex was one of the main reasons for the intra-population dietary variation. Ota males consumed greater amounts of marine food, while Ota females consumed greater amounts of terrestrial food; these dissimilar diets may have been related to the sexual division of labor. Significant inter-population dietary differences were found, which may have been related to differences in age or site location. Notably, the two coastal regions showed clear isotopic differences. Nitrogen isotope ratios of individuals from the Sanyo region were significantly higher than ratios of individuals from the Tokai region. The individuals in the Sanyo region might have consumed a diet high in aquatic foods, particularly high trophic level marine fish, whereas the individuals in the Tokai region might have consumed a lot of marine shellfish. Another possible reason for the regional isotopic difference might have been different baseline of nitrogen isotope ratios of the marine ecosystems.

Keywords: Jomon period; hunter-gatherers; human bone collagen; carbon; nitrogen; 
Journal of Archaeological Science, 37 (2010) 1968-1977

stable isotope. 
Journal of Archaeological Science, 37 (2010) 1968-1977

\section{Introduction}

The period of Jomon culture in the Japanese Archipelago lasted from 13000 to 2300 years BP. The Jomon people were hunter-gatherers who are well known for their cord-marked pottery. The Jomon people in general led a sedentary life, effectively exploiting marine and/or terrestrial resources; rice agriculture was not introduced until the following Yayoi period (see Habu, 2004; Kobayashi et al., 2004).

The diet of prehistoric populations is an important indicator of how they subsisted and adapted to the environment. Central to the subsistence of the Jomon people was their exploitation of a wide variety of wild seasonal food resources (Akazawa, 1986;

Kobayashi et al., 2004). Although the composition of meals of the Jomon population can be inferred from faunal and floral remains in excavated sites, the potential of these remains for reconstructing diet is limited, because food items actually ingested disappear from the site and food remains are subject to taphonomic bias due to decomposition in the soil. A further limitation is that although food remains at a given site may indicate the consumption of particular food items by site-dwellers as a whole, they give no indication of intra-population dietary differences.

Paleodietary reconstruction using carbon and nitrogen isotope analysis of human bone collagen is a widely used method to determine the diet of prehistoric populations (e.g., Ambrose and DeNiro, 1986; Craig et al., 2009; Hedges et al., 2008; Hu et al., 2009; Schulting et al., 2008; Walker and DeNiro, 1986). Isotope analysis is based on the principle that the tissues in an animal's body are derived from its dietary intake. Laboratory experiments have shown that the composition of an animal's body protein primarily reflects that animal's dietary protein intake (Ambrose and Norr, 1993; Tieszen and Fagre, 1993). The turnover rate of bone collagen in vivo is several years (Libby et al., 
1964; Stenhouse and Baxter, 1979), meaning that stable isotope ratios obtained from human skeletal remains record the average isotopic composition of an individual's dietary protein intake over the several years prior to death. Thus, stable isotope analysis can reconstruct the diet of prehistoric populations and has the potential for detecting dietary differences among individuals in these populations. Carbon stable isotope analysis is generally used to characterize a diet from $\mathrm{C}_{3}$ (plants adapted to temperate ecosystems, including most vegetables, fruit, and wheat) versus $\mathrm{C}_{4}$ (plants adapted to hot, arid ecosystems, including millet, maize, and sugarcane) ecosystems (Pate, 1995) or, in an environment without $\mathrm{C}_{4}$ plants, marine versus terrestrial ecosystems (Chisholm et al., 1982; Schoeninger et al., 1983; Sealy and van der Merwe, 1985; Tauber, 1983). Nitrogen stable isotopes reflect the position of an individual in the food chain, because body tissues show a $3-4 \%$ enrichment in $\delta^{15} \mathrm{~N}$ relative to diet (Minagawa and Wada, 1984;

Schoeninger and DeNiro, 1984).

Stable carbon and nitrogen isotope analysis of human bones from the Jomon period has been used in several studies (Chisholm et al., 1992; Kusaka et al., 2008; Minagawa and Akazawa, 1992; Minagawa, 2001; Roksandic et al., 1988; Yoneda et al., 1996, 2002, 2004). Previous isotopic studies have suggested the possibility of sex-based dietary differences in the Jomon population (Chisholm et al., 1992; Kusaka et al., 2008; Yoneda et al., 1996). Chisholm et al. (1992) suggested that the sex-related differences in isotopic values they observed in Hokkaido resulted from different modes of food acquisition in males and females: males hunted, while females fished and gathered plant food.

Investigating intra-population dietary differences could therefore reveal aspects of social organization in the prehistoric population.

In addition, Minagawa (2001) investigated isotopic differences in diet among a large 
Journal of Archaeological Science, 37 (2010) 1968-1977

number of the Jomon samples and found that the Hokkaido Jomon people seemed to depend largely on marine mammals and fish, the Jomon people of the Sanyo and Kyushu regions consumed large amounts of marine food, and the Jomon people of the Kanto and Tohoku regions, as well as the Inland Jomon people, consumed mainly terrestrial food. Minagawa (2001) suggested the possibility of regional dietary differences in Honshu, but this possibility has not been well investigated. Meanwhile, discriminant function analysis of two kinds of Jomon tool-kits, lithic and fishing, revealed four geographical groups of sites that adapted to different environments (Akazawa, 1986). The coastal Jomon societies of eastern Japan had a procurement system in a forest and estuarine/Pacific littoral ecosystem year round, while the western Jomon people, who lived in a forest and freshwater ecosystem, lacked marine product resources in spring and summer, and experienced seasonal resource depletion (Akazawa, 1999). In addition, regional differences of dental disease and systemic stress between Western and Eastern Japan have been suggested based on linear enamel hypoplasia (LEH) frequencies of Jomon skeletal remains. Temple (2007) found that western and inland sites showed higher LEH frequencies than eastern sites, and the differences were interpreted to reflect one of two possible reasons: firstly, seasonal stress from living in an environment where high caloric resources fluctuated seasonally; secondly, lack of nutrition from plant-based resources. In addition, equal levels of frequencies of caries in teeth of the Late-final Jomon samples between western and eastern Japan suggested that these populations consumed resources with comparable plant carbohydrates (Temple, 2007). These findings are, however, general trends of data sets, and Temple (2007) stated that inter-regional stress variation also played a significant role in directing the biological and cultural evolution of Jomon people. 
Journal of Archaeological Science, 37 (2010) 1968-1977

This study reports the results of carbon and nitrogen stable isotope analysis on Jomon samples from six sites in the Sanyo and Tokai regions of Honshu in Japan during the Middle to Final Jomon period (ca. 5000-2300 years BP). The Sanyo and Tokai regions are included in western and eastern Japan, respectively. Comparing the diets of these two regions is important because large quantities of Jomon skeletal remains have been recovered in these regions, and these skeletal remains have provided a significant contribution to the study of the physical anthropology of the Jomon period. Based on pollen analysis, the Middle Jomon period is considered to have been the warmest period in the Holocene, while the Late-Final Jomon period was a period of cooling (Tsukada, 1986). This study aimed: (a) to characterize the diet of the Jomon samples compared with estimated food sources; (b) to explore intra-population dietary differences by comparing isotopic values among subgroups according to sex; (c) to assess inter-population dietary differences in the Sanyo and Tokai regions; and (d) to assess regional dietary differences between the Sanyo and Tokai regions.

\section{Materials and Methods}

\subsection{Jomon sites in the Sanyo and Tokai regions}

Ninety-six skeletal remains from five Jomon sites of two coastal regions in Japan were studied (Tables 1, 2). Stable isotope data of Inariyama and Yoshigo individuals were published by Kusaka et al. (2008), and these data were used in order to compare diets in the two regions. The Sanyo region comprises the Ota, Funamoto, and Tsukumo shell mounds, and the Tokai region comprises the Kawaji, Inariyama, and Yoshigo shell mounds (Fig. 1). Animal skeletal remains from the Sanyo region (six deer, four boars, and eight fish) were also analyzed (Table 3). Faunal samples were from some but not all sites, 
Journal of Archaeological Science, 37 (2010) 1968-1977

and the sample size was small, but consisted of all available samples in our laboratory. All these sites were excavated by Prof. K. Kiyono (Kiyono, 1969), and the skeletal remains are stored in the Laboratory of Physical Anthropology, Faculty of Science, Kyoto University. Most of the samples were ribs; bone fragments were analyzed in some samples when ribs could not be obtained.

The Ota shell mound in Onomichi City, Hiroshima Prefecture was excavated in 1926. Approximately 55 skeletal remains were found together with stone tools and Jomon pottery (Kiyono, 1969). The skeletal remains of the Ota site have been dated to the Middle Jomon period (ca. 5000-4000 years BP) by pottery types (Shiomi et al., 1971). Twenty-five well-preserved human skeletons and the skeletal remains of one deer were selected for analysis.

The Funamoto shell mound is located in Kurashiki City, Okayama Prefecture. Fourteen skeletal remains were excavated in 1920. The Funamoto site has been dated to the Middle Jomon period by the Funamoto-shiki pottery type (Kawase, 2006). Nine human skeletal remains and the skeletal remains of one deer were selected for analysis.

The Tsukumo shell mound in Kasaoka City, Okayama Prefecture, was excavated in 1920-1922. Seventy-two individuals were found and dated to the Late-Final Jomon period (ca. 4000-2300 years BP). The Tsukumo shell mound is famous in Jomon archaeology because here, for the first time in Japan, the remains of a large number of Jomon skeletons were found. Most of the individuals are well preserved, and their sex and age can be estimated. Fifty-three samples were selected for isotope analysis. The remains of four deer, four boars, and eight fish (red sea bream) were obtained for analysis.

The Kawaji shell mound is located in Tahara City, Aichi Prefecture. Twenty-three 
individuals were excavated in 1922. The Kawaji site is dated to the middle part of the Late Jomon period (ca. 3700-3300 years BP). Skeletal remains of nine humans were selected for analysis.

The Inariyama shell mound is located in Hoi County, Aichi Prefecture. The Inariyama site was excavated in 1922, and about 60 human skeletons were recovered. The site is dated as extending from the middle part of the Final Jomon period (ca. 2800-2500 years BP) based on the chronology of pottery types. One individual was newly analyzed, and isotopic data of another 28 Inariyama individuals have been reported (Kusaka et al., 2008).

The Yoshigo shell mound is located on the northern coast of the Atsumi Peninsula, Aichi Prefecture. The mound was excavated in 1922. About 300 human skeletons were recovered. The site is dated as extending from the later part of the Late Jomon period to the Final Jomon period (ca. 3500-2300 years BP) based on the chronology of pottery types, which has been confirmed by radiocarbon dating of human skeletal remains (ca. 3200-2800 cal BP; Kusaka et al., 2009).

The sex of human bone samples was determined on the basis of hipbone morphologies (Phenice, 1969) and cranial features (Buikstra and Ubelaker, 1994). Age at death was estimated on the basis of the morphologies of the pubic symphysis (Brooks and Suchey, 1990), the auricular surface of the ilium (Lovejoy et al., 1985), cranial sutures (Meindl and Lovejoy, 1985), and dental attrition (Lovejoy, 1985).

\subsection{Collagen extraction and stable isotope measurements}

Bone collagen was extracted in the Laboratory of the Research Institute for Humanity and Nature. Extraction followed a modified Longin's (1971) method 
Journal of Archaeological Science, 37 (2010) 1968-1977

described by Yoneda et al. (2004). A bone sample of about $1 \mathrm{~g}$ was ultrasonically cleaned in pure water in order to remove any soil. Humic and fulvic acids were removed from the sample by soaking in $0.2 \mathrm{~mol} / \mathrm{L} \mathrm{NaOH}$ overnight and the sample was neutralized in pure water. The sample was lyophilized and crushed using a mill. The powdered sample was then sealed in a cellulose tube and soaked in $1 \mathrm{~mol} / \mathrm{L} \mathrm{HCl}$ overnight to remove hydroxyapatite. The sample in a cellulose tube was soaked in pure water to neutralize the sample. The remaining material in a cellulose tube was separated into the solid and liquid fractions by centrifugation, and the solid fraction was lyophilized. The solid sample was heated at $90^{\circ} \mathrm{C}$ for 12 hours in pure water to gelatinize the bone collagen. After centrifugation, the liquid fraction, which contained gelatinized bone collagen, was freeze-dried, and this collagen sample was used for isotopic analyses.

About $0.5 \mathrm{mg}$ of the extracted collagen was measured for carbon and nitrogen isotope ratios using an elemental analyzer (Flash EA) connected to an isotope ratio mass spectrometer (DELTA plus XP) by means of continuous flow (CONFLO III). The natural abundance of ${ }^{13} \mathrm{C}$ and ${ }^{15} \mathrm{~N}$ is expressed as per mil (\%o) deviation from international standards: $\delta^{13} \mathrm{C}$ or $\delta^{15} \mathrm{~N}=\left(\mathrm{R}_{\text {sample }} / \mathrm{R}_{\text {standard }}-1\right) \times 1000$, where $\mathrm{R}$ in $\delta^{13} \mathrm{C}$ or $\delta^{15} \mathrm{~N}$ is ${ }^{13} \mathrm{C} /{ }^{12} \mathrm{C}$ or ${ }^{15} \mathrm{~N} /{ }^{14} \mathrm{~N}$, respectively. Pee Dee belemnite (PDB) and atmospheric nitrogen were used as the international standards for carbon and nitrogen, respectively. Based on the standard materials measured with unknown samples, the measuring errors for each measurement were less than $0.2 \%$ for $\delta^{15} \mathrm{~N}$ values and less than $0.2 \%$ for $\delta^{13} \mathrm{C}$ values. 
Journal of Archaeological Science, 37 (2010) 1968-1977

\subsection{Statistical analysis}

The statistical software JMP (SAS institute) was used for statistical analysis. The Wilcoxon test was used to compare male with female data in each sample. Statistical significance was evaluated using the $P$ values of 0.05 .

Multiple regression analysis (the model: $\delta^{15} \mathrm{~N} \sim \delta^{13} \mathrm{C}+$ Site) and post hoc Tukey's HSD test were used to evaluate dietary differences among Sanyo samples. $\delta^{13} \mathrm{C}$ effect is a continuous variable, and Site effect is a categorical variable of the three Sanyo sites.

Analysis of covariance (ANCOVA; the model: $\delta^{15} \mathrm{~N} \sim \delta^{13} \mathrm{C}+$ Site $+\delta^{13} \mathrm{C}$ : Site) and post hoc multiple comparisons (ANCOVA on pairwise sites) were used to evaluate dietary differences among Tokai samples. Site effect is a categorical variable of the three Tokai sites, and $\delta^{13} \mathrm{C}$ :Site is the interaction of $\delta^{13} \mathrm{C}$ and Site effects. In the post hoc multiple comparisons, differences of slope of isotopic data among sites were evaluated based on the significance level of the interaction of $\delta^{13} \mathrm{C}$ and Site effects by using the $P$ values generated from the sequential Bonferroni test (Rice, 1989). If a collection of $k$ tests is simultaneously carried out, the sequential Bonferroni test ranks the $P$ values from smallest $\left(P_{1}\right)$ to largest $\left(P_{\mathrm{k}}\right)$, and statistical significance is judged by the $P_{\mathrm{i}}<\alpha /(1+$ $\mathrm{k}-\mathrm{i})$.

Multiple regression analysis was used to evaluate regional dietary differences between the Sanyo and Tokai regions based on the model: $\delta^{15} \mathrm{~N} \sim \delta^{13} \mathrm{C}+$ Region + Site[Region]. Region is a categorical variable of Sanyo and Tokai individuals. Site[Region] is a random effect of the six sites nested in Region. 
Journal of Archaeological Science, 37 (2010) 1968-1977

\section{Results}

\subsection{Collagen preservation}

The carbon and nitrogen stable isotope ratios and $\mathrm{C} / \mathrm{N}$ ratios of all the subjects' bone samples are listed in Tables 2 and 3. It was confirmed that diagenetic effects did not influence these ratios based on the quality indicator of $\mathrm{C} / \mathrm{N}$ ratios (2.9 to 3.6; DeNiro, 1985).

\subsection{Stable isotope ratios of animal remains}

The stable isotope results of animals showed a reasonable range, which is expected from their known feeding habits. Deer samples had a mean $\delta^{13} \mathrm{C}$ value of $-21.3 \pm 1.4 \%$ and a mean $\delta^{15} \mathrm{~N}$ value of $4.8 \pm 0.5 \%$. Isotope values of deer were in the same range as those for Jomon deer samples previously reported $\left(-21.2 \pm 0.7 \%\right.$ for $\delta^{13} \mathrm{C}, 5.0 \pm 1.8 \%$ for $\delta^{15} \mathrm{~N}, \mathrm{n}=5$; Minagawa, 2001). Boar samples showed a mean $\delta^{13} \mathrm{C}$ value of $-20.1 \pm 1.4 \%$ o and a mean $\delta^{15} \mathrm{~N}$ value of $6.0 \pm 1.2 \%$. These values are slightly higher than those of deer, which can be explained by their diet: boars are omnivores, while deer are herbivores. Fish samples showed a mean $\delta^{13} \mathrm{C}$ value of $-11.7 \pm 0.9 \%$ and a mean $\delta^{15} \mathrm{~N}$ value of $13.4 \pm$ $0.8 \%$, and were thus in the expected range for fish in the Inland Sea $(-11.0 \pm 1.1 \%$ for $\delta^{13} \mathrm{C}, 13.1 \pm 1.1 \%$ for $\delta^{15} \mathrm{~N}, \mathrm{n}=31$; Ishimaru et al., 2008).

\subsection{Isotope ratios of human bone collagen}

\subsubsection{Intra-population isotopic variation}

Results of stable isotope analysis on all human bone collagen are summarized in Table 4, and plotted in Fig. 2. Ota individuals showed wide isotope variation, particularly in $\delta^{15} \mathrm{~N}$. Carbon and nitrogen isotopic values of Ota individuals were significantly 
positively correlated $\left(R^{2}=0.89, P<0.0001\right)$.

Funamoto individuals showed the highest mean isotope ratios in both $\delta^{13} \mathrm{C}$ and $\delta^{15} \mathrm{~N}$ compared to the individuals from other sites (Table 4). Carbon and nitrogen isotope values of Funamoto individuals were significantly positively correlated $\left(R^{2}=0.79, P<\right.$ $0.0014)$.

Tsukumo individuals showed slightly lower isotopic values than Ota and Funamoto individuals. Carbon and nitrogen isotope ratios were significantly correlated $\left(R^{2}=0.87, P\right.$ $<0.0001)$. They showed the widest variation in $\delta^{15} \mathrm{~N}$ values. Five individuals in particular had lower $\delta^{15} \mathrm{~N}$ values with a large range (5.4 to 9.1\%o), and lower $\delta^{13} \mathrm{C}$ values with a narrow range $(-19.7$ to $-19.1 \%)$. This might indicate dietary consumption of terrestrial mammals and $\mathrm{C}_{3}$ plants.

Kawaji individuals showed higher $\delta^{13} \mathrm{C}$ than Ota, Funamoto, and Tsukumo individuals. Carbon and nitrogen isotope values of Kawaji individuals were not significantly correlated $\left(R^{2}=0.39, P<0.0715\right)$.

Carbon and nitrogen isotope ratios of one Inariyama individual were within the range of other Inariyama individuals previously reported by Kusaka et al. (2008).

\subsubsection{Comparison of possible food sources}

In order to characterize the diet of the Jomon samples, isotope ratios of all human bone samples were compared with those of estimated food protein sources (Fig. 2). The values of the isotopic fractionation between animal bone collagen and human bone collagen, $1 \%$ for $\delta^{13} \mathrm{C}$ and $3.4 \%$ for $\delta^{15} \mathrm{~N}$, were added to those of protein sources (Ambrose, 1993; Bocherens and Drucker, 2003; Minagawa and Wada, 1984; Schoeninger and DeNiro, 1984). The isotopic data on terrestrial mammals (deer and boar) and marine 
Journal of Archaeological Science, 37 (2010) 1968-1977

fish (red sea bream) of this study were used for the comparison. Isotope ratios from Yoneda et al. (2004) of estimated food protein sources for the Jomon samples $\left(\mathrm{C}_{3}\right.$ plants, freshwater fish, marine shellfish) were used. The values of the isotopic fractionation between food proteins and human bone collagen, $4.5 \%$ for $\delta^{13} \mathrm{C}$ and $3.4 \%$ for $\delta^{15} \mathrm{~N}$, were added to those of the protein sources (Ambrose, 1993; Minagawa and Wada, 1984; Schoeninger and DeNiro, 1984). Humans would show these corrected isotope ratios of a protein source when they had fully consumed the protein source. All isotopic values of protein sources, corrected for isotope fractionation, are listed in Table 5. The ranges of commonly used fractionation values between diet and human collagen are $4.5-6.1 \%$ for $\delta^{13} \mathrm{C}$ and $3-5 \%$ for $\delta^{15} \mathrm{~N}$ (Ambrose, 1993; Hedges and Reynard, 2007). We selected the above fractionation values for a tentative comparison of human bone collagen and dietary sources, which have been used by Kusaka et al. (2008) and Yoneda et al. (2004) for Jomon samples. Since isotope ratios of protein sources vary widely, it would be possible to characterize general dietary trends of Jomon people based on comparison between isotope ratios of human bones and corrected values of protein sources.

As shown in Fig. 2, isotope ratios of human bone collagen were distributed in the range for these protein sources. Most individual ratios were distributed between terrestrial and marine resources, and some individual ratios were distributed between terrestrial mammals and $\mathrm{C}_{3}$ plants. The correlation between $\delta^{13} \mathrm{C}$ and $\delta^{15} \mathrm{~N}$ would be the result of a dietary mix of terrestrial and marine resources.

\subsubsection{Effect of sex on isotopic composition}

Interestingly, there was a significant difference in isotopic values between males and females of the Ota samples (Wilcoxon test, $\chi^{2}=7.22, P=0.0072$ for $\delta^{13} \mathrm{C} ; \chi^{2}=6.49, P=$ 
0.0108 for $\delta^{15} \mathrm{~N}$; Fig. 3). Males $\left(-16.2 \pm 0.7 \%\right.$ for $\delta^{13} \mathrm{C}, 13.7 \pm 1.3 \%$ for $\left.\delta^{15} \mathrm{~N}\right)$ showed slightly higher $\delta^{13} \mathrm{C}$ and $\delta^{15} \mathrm{~N}$ values than females $\left(-17.3 \pm 1.1 \%\right.$ for $\delta^{13} \mathrm{C}, 11.9 \pm 2.0 \%$ o for $\delta^{15} \mathrm{~N}$ ), suggesting that Ota males consumed greater amounts of marine foods and that females consumed greater amounts of terrestrial foods.

\subsubsection{Inter-population dietary difference in each region}

Statistical analysis of isotopic data showed significant differences in diet among samples from the Sanyo region. Isotopic variation of samples from the Sanyo region can be explained by multiple regressions with equal slopes and different intercepts (multiple regression analysis: $F=558.9, P<0.0001$ for $\delta^{13} \mathrm{C} ; F=21.1, P<0.0001$ for Site; Fig. 4a). Tsukumo samples showed significantly lower $\delta^{15} \mathrm{~N}$ than Ota and Funamoto samples (post hoc Tukey's HSD test on the difference of least squares means [LSMeans]: LSMean $\delta^{15} \mathrm{~N}$ $=13.2$ for Ota; LSMean $\delta^{15} \mathrm{~N}=13.1$ for Funamoto; LSMean $\delta^{15} \mathrm{~N}=12.1$ for Tsukumo: $P$ $<0.05$ for Tsukumo vs. Ota, $P<0.05$ for Tsukumo vs. Funamoto, and not significant for Ota vs. Funamoto).

Statistical analysis of isotopic data also showed significant differences in diet among samples from the Tokai region. The isotopic variation of samples from the Tokai region can be explained by multiple regressions with different slopes and intercepts (ANCOVA: $F=115.0, P<0.0001$ for $\delta^{13} \mathrm{C} ; F=18.8, P<0.0001$ for Site; $F=10.1, P=0.0001$ for the interaction of $\delta^{13} \mathrm{C}$ and Site; Fig. 4b). Post hoc multiple comparison of each regression line suggested that the slope of the regression line of the Yoshigo data was higher than that of Inariyama data but not significantly higher than that of Kawaji data, and the slopes of Kawaji and Inariyama data were not significantly different (ANCOVA: $P<0.0001$ for the interaction of $\delta^{13} \mathrm{C}$ and Site for Yoshigo vs. Inariyama; but not significant for the 
Journal of Archaeological Science, 37 (2010) 1968-1977

interaction of $\delta^{13} \mathrm{C}$ and Site for Yoshigo vs. Kawaji, and Kawaji vs. Inariyama).

\subsubsection{Regional dietary differences}

Multiple regression analysis of all data from the six sites showed significant differences between the two regions (the model: $\delta^{15} \mathrm{~N} \sim \delta^{13} \mathrm{C}+$ Region + Site[Region], $F$ $=638.0, P<0.0001$ for $\delta^{13} \mathrm{C}, F=32.5, P=0.0042$ for Region, LSMean $\delta^{15} \mathrm{~N}=12.9$ for Sanyo individuals, LSMean $\delta^{15} \mathrm{~N}=10.5$ for Tokai individuals). The Sanyo samples showed significantly higher $\delta^{15} \mathrm{~N}$ than the Tokai samples, by $2.4 \%$.

\section{Discussion}

\subsection{Characterizing the diet of the Jomon people in the coastal area}

Carbon and nitrogen isotope data of human bones were widely distributed in the range of protein food sources, and suggest that all of the examined Jomon populations consumed these foods (Fig. 2). The $\delta^{13} \mathrm{C}$ and $\delta^{15} \mathrm{~N}$ values of human bone collagen were positively correlated within each site, indicating that a dietary mixing between marine and terrestrial foods caused intra-site dietary differences. A positive linear correlation between $\delta^{13} \mathrm{C}$ and $\delta^{15} \mathrm{~N}$ of human bone collagen was also found in southern Californian Native Americans (Walker and DeNiro, 1984), coastal Mesolithic people in Europe (Richards and Hedges, 1999), and southernmost African hunter-gatherers (Sealy, 2006). This tendency is probably characteristic of populations with access to both marine and terrestrial food sources. In a simple linear mixing model that assumes $17 \%$ of $\delta^{15} \mathrm{~N}$ for $100 \%$ marine food consumers and $9 \%$ of $\delta^{15} \mathrm{~N}$ for $100 \%$ terrestrial mammal consumers, an individual who has $15 \%$ of $\delta^{15} \mathrm{~N}$ in bone collagen would consume $75 \%$ marine meat and $25 \%$ terrestrial meat. Individuals who showed about $-19 \%$ for $\delta^{13} \mathrm{C}$ and $9 \%$ for $\delta^{15} \mathrm{~N}$ 
Journal of Archaeological Science, 37 (2010) 1968-1977

mainly consumed meat of terrestrial mammals and $C_{3}$ plants. Individuals who showed about $-19.5 \%$ for $\delta^{13} \mathrm{C}$ and $5 \%$ for $\delta^{15} \mathrm{~N}$ would be $100 \% \mathrm{C}_{3}$ plant consumers. The present study suggests that most of the Jomon people examined consumed both marine and terrestrial protein, while a small number of Jomon people consumed exclusively terrestrial meat and plants. Such intra-site dietary differences characterize the diet of Jomon people living in the coastal area of Honshu.

\subsection{Intra-population dietary differences by sex}

Sexual differences in isotopic data suggest that Ota males consumed a greater amount of marine foods, whereas females consumed more terrestrial mammals and plants (Fig. 3). Pervasive food sharing between males and females in hunting/gathering subsistence economies is largely accepted (Bird, 1999; Kaplan and Hill, 1985; Winterhalder, 1996), with the result that dietary differences by sex are not evident. However, in some ethnographic records, differential access to animal meat and fat was reported: males often ate the fatty parts of meat while females obtained lesser amounts of animal fat (Kelly, 1995). The dietary difference between sexes might have been a result of differential access to foods, and might have been related to the sexual division of labor among the Ota individuals. Ota males may have been engaged in fishing, while females may have been engaged in plant gathering, resulting in high frequencies of eating fish for males and plants for females. This possibility is supported by the high prevalence of auditory exostosis in Ota males. Auditory exostoses, which are bony lesions of the external auditory canal, are associated with the exploitation of cold water food resources (DiBartolomeo, 1979; Kennedy, 1986). Miyake and Imamichi (1931) found auditory exostoses in $25.7 \%$ of Ota male crania but none in female crania. Katayama (1998), who 
Journal of Archaeological Science, 37 (2010) 1968-1977

also investigated the frequency of auditory exostoses among many Jomon samples throughout the Japanese Archipelago, suggested that males of the Sanyo samples, including the Ota samples, had a high frequency of auditory exostoses $(21.4 \%)$, while no females had auditory exostoses. These studies suggest that Ota males were engaged in fishing to exploit marine resources, resulting in higher consumption of marine food.

Another possible explanation is that the observed difference between sexes results from an exogamous, patrilocal marriage pattern, with females moving from inland settlements where diet had lower $\delta^{13} \mathrm{C}$ and $\delta^{15} \mathrm{~N}$ values. This possibility has been discussed in other stable isotope studies on human bone collagen (Schulting and Richards, 2001; Richards and Mellars, 1998; Walker and DeNiro, 1986). Since most females had lower $\delta^{13} \mathrm{C}$ and $\delta^{15} \mathrm{~N}$ values than males in the Ota samples, marriage alone cannot explain the isotopic differences between the sexes. Two females who had particularly low isotopic values might have been immigrants from inland settlements (Fig. 3). Future strontium isotope analysis on the Ota samples would confirm such female immigration.

Stable isotope data from other Jomon sites have also suggested differences between the sexes in dietary intake, with varying trends. Dietary differences between sexes in the Yoshigo and Inariyama samples have been reported previously, and showed that the variation in $\delta^{15} \mathrm{~N}$ values was significant in males, although the mean $\delta^{15} \mathrm{~N}$ values did not differ (Kusaka et al., 2008). At the Kitamura site in Nagano Prefecture, males had a higher average $\delta^{13} \mathrm{C}$ value than females (Yoneda et al., 1996), as did Ota individuals. In Hokkaido samples, females had higher mean $\delta^{13} \mathrm{C}$ value than males (Chisholm et al., 1992). These findings cannot conclusively show a clear tendency for dietary differences between sexes, but do suggest that diet varied according to sex in Jomon society. 
Journal of Archaeological Science, 37 (2010) 1968-1977

\subsection{Inter-population dietary differences within geographic regions}

Comparison of isotopic data in each region showed significant differences in diet between sites. In the Sanyo region, the $\delta^{15} \mathrm{~N}$ values of Ota and Funamoto individuals were about $1 \%$ higher than those of Tsukumo individuals, implying that a higher proportion of dietary protein of Ota and Funamoto individuals was derived from high trophic level marine fish. The Ota and Funamoto sites are dated to the Middle Jomon period, while the Tsukumo site is dated to the Late-Final Jomon period. The observed dietary difference may be associated with this difference in site age. Based on pollen analysis, the climate of the Holocene is known to have been the warmest during 6000-4000 years BP, becoming cooler during 4000-1500 years BP (Tsukada, 1986). Evidence of resource instability from the Middle to Final Jomon period has been reported. Tooth caries frequencies of the Middle Jomon samples were lower than those of the Late-Final Jomon samples (Fujita, 1995; Temple, 2007). This suggests a subsistence shift in response to a climatic change and increased carbohydrate consumption among the people of the Late-Final Jomon period, which is consistent with our results showing a dietary shift at the end of the Middle Jomon period.

In the Tokai samples, the mean $\delta^{13} \mathrm{C}$ and $\delta^{15} \mathrm{~N}$ values of the Kawaji samples were higher than those of Yoshigo and Inariyama samples, which can be explained by the evidence of faunal bone remains. Excavation of faunal bones revealed that in the western part of the Atsumi Peninsula, tuna and sharks in the Pacific Ocean would have been mainly fished, while in the eastern part of the Atsumi Peninsula and along the eastern coast of Mikawa Bay, breams and clams would have been fished, although fishing was generally less active than in the west (Toizumi, 2000). Furthermore, auditory exostosis was frequently found among Kawaji crania, but not among Yoshigo and Inariyama crania 
Journal of Archaeological Science, 37 (2010) 1968-1977

(Kiyono, 1949; Yorimitsu, 1935), which suggests that marine fishing in the Kawaji individuals was intensive. The higher $\delta^{15} \mathrm{~N}$ values of Kawaji individuals reflects a high level of dependence on fishing of high trophic level fish at Mikawa Bay and the open sea of the Pacific Ocean.

The slope of the regression line of the Inariyama data was significantly lower than that of the Yoshigo data, indicating that the Inariyama individuals exploited lower trophic level fish and marine shellfish. The Muro shell mounds, which consist of large numbers of clams, were made during the Final Jomon period, which is contemporaneous with the Inariyama site (Toizumi, 2000, 2008). The site is considered to be an exploitation site of the common oriental clam. The Muro shell mound is located about 5 kilometers south of the Inariyama shell mound, and the Inariyama individuals might have consumed the shellfish exploited at the Muro shell mounds, resulting in a lower $\delta^{15} \mathrm{~N}$ yield in their bone collagen. In sum, the humans in the Tokai region appear to have developed subsistence behaviors adapted to the environment and resources of the site locations.

\subsection{Inter-regional dietary differences}

When individual data were pooled in each region (Sanyo and Tokai), the Sanyo samples showed significantly higher $\delta^{15} \mathrm{~N}$ values but no differences in $\delta^{13} \mathrm{C}$ values in comparison to the Tokai samples. This result is clearly shown in the higher $\delta^{13} \mathrm{C}$ values (>-18\%), but not in the $\delta^{13} \mathrm{C}$ values of about $-19 \%$ (Fig. 2), suggesting that consumption of food sources higher in $\delta^{15} \mathrm{~N}$ and $\delta^{13} \mathrm{C}$ in the Sanyo individuals was responsible for the dietary differences. The regional isotopic difference among the Jomon samples could have several explanations.

Firstly, we suggest that aquatic (marine and freshwater) fish were more important in 
Journal of Archaeological Science, 37 (2010) 1968-1977

the diet of the Sanyo individuals than in that of the Tokai individuals. Higher trophic level marine fish in particular would have elevated the $\delta^{15} \mathrm{~N}$ values of the Sanyo samples. Freshwater fish might also have been important for the Sanyo individuals. The $\delta^{13} \mathrm{C}$ values of freshwater fish are lower than those of marine fish, and the $\delta^{15} \mathrm{~N}$ values are intermediate between those of terrestrial mammals and marine fish (Dufour et al., 1999; Yoneda et al., 2004). Freshwater fish consumption may have caused higher $\delta^{15} \mathrm{~N}$ among the Sanyo samples. However, the regression lines of $\delta^{15} \mathrm{~N}$ and $\delta^{13} \mathrm{C}$ of the Sanyo samples generally show higher slopes than those of the Tokai samples, implying that marine fish could be the most likely explanation for the elevated $\delta^{15} \mathrm{~N}$ values of the Sanyo samples. Meanwhile, food sources lower in $\delta^{15} \mathrm{~N}$, such as marine shellfish, contributed much to the diet of the Tokai individuals. This is appears to be compatible with regional differences of the ecosystem and adaptation of Jomon people (Akazawa, 1999). Akazawa (1999) proposed that Jomon people in western Japan likely consumed a lot of marine resources but were still living within an ecosystem that did not provide access to these nutritious foods year round, while Jomon people in eastern Japan had access to marine shellfish and finfish throughout the year in an embayment condition. The results of our study suggest that the individuals of the Sanyo region could not exploit enough marine shellfish to compensate for seasonal resource depletion, while the individuals of the Tokai region could consume enough marine foods even in spring and summer. In addition, the trend is consistent with the study of enamel hypoplasia (Temple, 2007). The high frequency of enamel hypoplasia among western Jomon people might have resulted from the stress of seasonal resource depletion.

Secondly, regional dietary differences between the two regions may have been caused by regional differences in the $\delta^{15} \mathrm{~N}$ baseline in the marine ecosystems. To verify this, 
Journal of Archaeological Science, 37 (2010) 1968-1977

comparison of the $\delta^{13} \mathrm{C}$ and $\delta^{15} \mathrm{~N}$ values of fish between the Sanyo and Tokai regions is needed; however, our marine fish data are limited to the Sanyo region. Regional differences in $\delta^{15} \mathrm{~N}$ in archaeological marine fish bones have been observed between the Inland Sea and the Sea of Japan, and the $\delta^{15} \mathrm{~N}$ values of marine fish from the Inland Sea are $2-4 \%$ higher than those from the Sea of Japan, probably due to the different isotopic composition of dissolved organic matter and/or different trophic levels even in the same species (Ishimaru et al., 2008). Such differences between the Inland Sea and the Pacific Ocean are crucial to interpreting the isotopic data of the Jomon samples. The $\delta^{15} \mathrm{~N}$ values of modern marine fish (red sea bream, black porgy, and largescale blackfish) reveal that $\delta^{15} \mathrm{~N}$ of fish in the Pacific Ocean is about 1\%o lower than that of fish in the Inland Sea. We assume here that such regional differences in $\delta^{15} \mathrm{~N}$ in marine ecosystems also occurred during the Jomon period.

Regional differences in the $\delta^{15} \mathrm{~N}$ values between the Sanyo and Tokai samples were about 2.4\%o. The regional differences in baseline $\delta^{15} \mathrm{~N}$ in the sea explain $1 \%$ of the regional differences of the $\delta^{15} \mathrm{~N}$ values. The remaining difference of the $\delta^{15} \mathrm{~N}$ values of $1.4 \%$ would be related to the regional dietary differences in the amounts of marine fish.

Although the Sanyo samples are from the Middle to Final Jomon period, and the Tokai samples are from the Late to Final Jomon period, this age gap alone cannot account for the observed regional differences. The Tsukumo samples of the Late to Final Sanyo Jomon showed higher $\delta^{15} \mathrm{~N}$ values than the contemporaneous Yoshigo and Inariyama samples of the Tokai region. It is clear that there were dietary differences between the two regions during the Late to Final Jomon period. Future research needs to include samples from the Tokai region of the Middle Jomon period to test the dietary differences of the Jomon people between the two regions of that age. 
Journal of Archaeological Science, 37 (2010) 1968-1977

Because there were no regional differences in the $\delta^{13} \mathrm{C}$ values, we propose that the proportions of plant sources consumed in the two regions did not differ greatly. This general trend may be compatible with the lack of regional difference of caries teeth frequencies and stature between western and eastern Jomon people (Temple, 2007, 2008). However, dietary dependence on plant sources, which are a rich source of carbohydrates with low amounts of protein, should be explored through stable carbon isotope analysis of tooth enamel, since stable isotope ratios of bone collagen mainly reflect dietary protein sources, while stable isotope ratios of tooth enamel reflect dietary whole carbon sources (Ambrose and Norr, 1993).

\section{Conclusions}

The present study used isotopic data to characterize the diet of the Jomon samples of two coastal regions of Honshu, Japan. While the people producing both samples effectively exploited marine and terrestrial protein resources, the proportion of dietary marine and terrestrial protein varied among individuals. In the Ota samples, diet differed between the sexes: Ota males consumed marine food high in dietary proteins, while Ota females consumed terrestrial food. This may have been related to sexual division of labor in their society. In the Sanyo region, samples of the Middle Jomon period indicated that the people consumed slightly higher trophic level marine foods in comparison with those of the Late-Final Jomon period. In the Tokai region, in contrast, dietary differences were associated with site location and fishing strategies. Assessing the inter-population variability of isotopic values revealed regional isotopic differences between the Sanyo and Tokai samples. Higher trophic level marine fish consumption of the individuals of the Sanyo region and marine shellfish consumption of the individuals of the Tokai region are 
Journal of Archaeological Science, 37 (2010) 1968-1977

the most likely explanation for this result, although uncertainty remains about regional differences in the $\delta^{15} \mathrm{~N}$ baseline of marine ecosystems. This study provided evidence for inter- and intra-population dietary differences and inter-regional dietary differences in the Sanyo and Tokai regions, and provided new insight into the subsistence and adaptation to the environment among Holocene hunter-gatherers in Japan.

\section{Acknowledgements}

The authors wish to thank K. Katayama (Kyoto University), M. Yoneda (The University of Tokyo), I. Tayasu (Kyoto University), T. Ikarashi (Kyoto University), E. Nakajima (Kyoto University), and members of the Laboratory of Physical Anthropology, Kyoto University for their helpful discussions and comments, as well as E. Ishimaru (RIHN) and the members of Project D-02 of RIHN for their assistance with this study. Finally, we would like to thank two anonymous reviewers for their insightful comments and positive criticisms of our original manuscript. The study was performed as a part of Project D-02, “A New Cultural and Historical Exploration into Human-Nature Relationships in the Japanese Archipelago" at RIHN, and was funded by Research Fellowships of the Japan Society for the Promotion of Science for Young Scientists and by MEXT Global COE Program A06 of Kyoto University. 
Journal of Archaeological Science, 37 (2010) 1968-1977

\section{References}

Akazawa, T., 1986. Regional variation in procurement systems of Jomon hunter-gatherers, in: Akazawa, T., Aikens, C.M. (Eds.), Prehistoric Hunter-gatherers in Japan - New Research Methods. The University Museum, The University of Tokyo, Tokyo, pp. 73-89.

Akazawa, T., 1999. Regional variation in Jomon hunting-fishing-gathering societies, in: Omoto, K. (Ed.), Interdisciplinary Perspectives on the Origins of the Japanese. International Research Center for Japanese Studies, Kyoto, pp. 223-231.

Ambrose, S.H., 1993. Isotopic analysis of paleodiet: Methodological and interpretive considerations, in: Sandford, M.K. (Ed.), Investigation of Ancient Human Tissue. Gordon and Breach, Langhorne, pp. 59-130.

Ambrose, S.H., DeNiro, M.J., 1986. Reconstruction of African human diet using bone collagen carbon and nitrogen isotope ratios. Nature. 319, 321-324.

Ambrose, S.H., Norr, L., 1993. Experimental evidence for the relationship of the carbon isotope ratios of whole diet and dietary protein to those of bone collagen and carbonate, in: Lambert, J.B., Grupe, G. (Eds.), Prehistoric Human Bone Archaeology at the Molecular Level. Springer-Verlag, Berlin, pp. 1-38.

Benimura, H., 1984. Prehistoric Sites of Tokai Region. Nishino-insatsu, Gifu.

Bird, R., 1999. Cooperation and conflict: The behavioral ecology of the sexual division of labor. Evol. Anthrop. 8, 65-75.

Bocherens, H., Drucker, D., 2003. Trophic level isotopic enrichment of carbon and nitrogen in bone collagen: case studies from recent and ancient terrestrial ecosystems. Int. J. Osteoarchaeol. 13, 46-53.

Brooks, S., Suchey, J.M., 1990. Skeletal age determination based on the os pubis: A 
Journal of Archaeological Science, 37 (2010) 1968-1977

comparison of the Acsádi-Nemeskéri and Suchey-Brooks methods. Hum. Evol. $5,227-238$.

Buikstra, J.E., Ubelaker, D.H., 1994. Standards for Data Collection from Human Skeletal Remains. Arkansas Archaeological Survey, Fayetteville, Arkansas.

Chisholm, B.S., Koike, H., Nakai, N., 1992. Carbon isotopic determination of paleodiet in Japan: Marine versus terrestrial sources, in: Aikens, C.M., Rhee, S.N. (Eds.), Pacific northeast Asia in Prehistory: Research into the Emergence of Hunter-fisher-gatherers, Farmers and Socio-political Elites. University Washington Press, Washington, pp. 69-73.

Chisholm, B.S., Nelson, D.E., Schwarcz, H.P., 1982. Stable-carbon isotope ratios as a measure of marine versus terrestrial protein in ancient diets. Science. $216,1131-$ 1132.

Craig, O.E., Biazzo, M., O'Connell, T.C., Garnsey, P., Martinez-Labarga, C., Lelli, R., Salvadei, L., Tartaglia, G., Nava, A., Renò, L., Fiammenghi, A., Rickards, O., Bondioli, L., 2009. Stable isotopic evidence for diet at the Imperial Roman coastal site of Velia (1st and 2nd Centuries AD) in Southern Italy. Amer. J. Phys. Anthrop. 139, 572-583.

DeNiro, M.J., 1985. Postmortem preservation and alteration of in vivo bone collagen isotope ratios in relation to palaeodietary reconstruction. Nature. $317,806-809$.

DiBartolomeo, J., 1979. Esoxtoses of the external auditory canal. Ann. Otol. Rhinol. Laryngol. (Suppl. 61). 88, 1-17.

Dufour, E., Bocherens, H., Mariotti, A., 1999. Palaeodietary implications of isotopic variability in Eurasian lacustrine fish. J. Archaeol. Sci. 26, 617-627.

Fujita, H., 1995. Geographical and chronological differences in dental caries in the 
Journal of Archaeological Science, 37 (2010) 1968-1977

Neolithic Jomon period of Japan. Anthropl. Sci. 103, 23-37.

Habu, J., 2004. Ancient Jomon of Japan. Cambridge University Press, Cambridge.

Hedges, R.E.M., Reynard, L.M., 2007. Nitrogen isotopes and the trophic level of humans in archaeology. J. Archaeol. Sci. 34, 1240-1251.

Hedges, R.E.M., Saville, A., O'Connell, T., 2008. Characterizing the diet of individuals at the Neolothic chambered tomb of Hazleton North, Gloucestershire, England, using stable isotope analysis. Archaeometry. 50, 114-128.

Hu, Y., Shang, H., Tong, H., Nehlich, O., Liu, W., Zhao, C., Yu, J., Wang, C., Trinkaus, E., Richards, M.P., 2009. Stable isotope dietary analysis of the Tianyuan 1 early modern human. Proc. Natl. Acad. Sci. U.S.A. 106, 10971-10974.

Ishimaru, E., Umino, T., Yoneda, M., Shibata, Y., Yumoto, T., Tayasu, I., 2008.

Expansion in the distribution of marine products revealed by the identification of marine fish origins: a new perspective from carbon and nitrogen stable isotope data from Chugoku and Shikoku. Archaeol. Nat. Sci. 57, 1-20 (in Japanese with English abstract).

Kaplan, H. and Hill, K., 1985. Food sharing among Ache foragers: tests of explanatory hypotheses. Curr. Anthrop. 26, 223-246.

Katayama K., 1998. Auditory exostoses among Jomon people: the distribution and the possible causative factors. Bull. Kashiwara Archaeol. Inst. 13, pp. 423-438 (in Japanese).

Kawase, M., 2006. Jomon Shell Mounds of Kibi. Kibijin-shuppan, Okayama (in Japanese).

Kelly, R.L., 1995. The Foraging Spectrum: Diversity in Hunter-Gatherer Lifeways. Smithsonian Institution Press, Washington, DC. 
Journal of Archaeological Science, 37 (2010) 1968-1977

Kennedy, G.E., 1986. The relationship between auditory exostoses and cold water: A latitudinal analysis. Amer. J. Phys. Anthrop. 71, 401-415.

Kiyono, K., 1949. Study of the Japanese Population Based on Ancient Human Skeletal Remains (Kodai jinkotsu no kenkyu ni motozuku nihon jinshu ron). Iwanami shoten, Tokyo (in Japanese).

Kiyono, K., 1969. Study of Japanese Shell Middens (Nihon kaizuka no kenkyu). Iwanami Shoten, Tokyo (in Japanese).

Kobayashi, T., Kaner, S., Nakamura, O., 2004. Jomon Reflections: Forager Life and Culture in the Prehistoric Japanese Archipelago. Oxbow Books, Oxford.

Kusaka, S., Ando, A., Nakano, T., Yumoto, T., Ishimaru, E., Yoneda, M., Hyodo, F., Katayama, K., 2009. A strontium isotope analysis on the relationship between ritual tooth ablation and migration among the Jomon people in Japan. J. Archaeol. Sci. 36, 2289- 2297.

Kusaka, S., Ikarashi, T., Hyodo, F., Yumoto, T., Katayama, K., 2008. Variability in stable isotope ratios in two Late-Final Jomon communities in the Tokai coastal region and its relationship with sex and ritual tooth ablation. Anthrop. Sci. 116, 171181.

Libby, W.F., Berger, R., Mead, J.F., Alexander, G.V., Ross, J.F., 1964. Replacement rates for human tissue from atmospheric radiocarbon. Science. 146, 1170-1172.

Longin, R., 1971. New method of collagen extraction for radiocarbon dating. Nature. 230, $241-242$.

Lovejoy, C.O., 1985. Dental wear in the Libben population: Its functional pattern and role in the determination of adult skeletal age at death. Amer. J. Phys. Anthrop. 68, $47-56$. 
Journal of Archaeological Science, 37 (2010) 1968-1977

Lovejoy, C.O., Meindl, R.S., Pryzbeck, T.R., Mensforth, R.P., 1985. Chronological metamorphosis of the auricular surface of the ilium: A new method for the determination of adult skeletal age at death. Amer. J. Phys. Anthrop. 68, 15-28.

Meindl, R.S., Lovejoy, C.O., 1985. Ectocranial suture closure: A revised method for the determination of skeletal age at death based on the lateral-anterior sutures. Amer. J. Phys. Anthrop. 68, 57-66.

Minagawa, M., 2001. Dietary pattern of prehistoric Japanese populations inferred from stable carbon and nitrogen isotopes in bone protein, Bulletin of the National Museum of Japanese History. 86, 333-357 (in Japanese with English abstract).

Minagawa, M., Akazawa, T., 1992. Dietary patterns of Japanese Jomon hunter-gatherers: Stable nitrogen and carbon isotope analyses of human bones, in: Aikens, C.M., Rhee, S.N. (Eds.), Pacific Northeast Asia in Prehistory: Research into the Emergence of Hunter-fisher-gatherers, Farmers and Socio-political Elites. University Washington Press, Washington, pp. 59-68.

Minagawa, M., Wada, E., 1984. Stepwise enrichment of ${ }^{15} \mathrm{~N}$ along food chains: Further evidence and the relation between $\delta^{15} \mathrm{~N}$ and animal age. Geochim. Cosmochim. Acta. 48, 1135-1140.

Miyake, S., Imamichi, S., 1931. Auditory exostoses among Ota human skeletal remains of Bingo County. J. Anthrop. Soc. Nippon. 46, 709-718.

Pate, F.D., 1995. Stable carbon isotope assessment of hunter-gatherer mobility in prehistoric South Australia. J. Archaeol. Sci. 22, 81-87.

Phenice, T., 1969. A newly developed visual method of sexing in the Os Pubis. Amer. J. Phys. Anthrop. 30, 297-301.

Rice, W.R., 1989. Analyzing tables of statistical tests. Evolution. 43, 223-225. 
Journal of Archaeological Science, 37 (2010) 1968-1977

Richards, M.P., Hedges, R.E.M., 1999. Stable isotope evidence for similarities in the types of marine foods used by Late Mesolithic humans at sites along the Atlantic coast of Europe. J. Archaeol. Sci. 26, 717-722.

Richards, M.P., Mellars, P.A., 1998. Stable isotopes and the seasonality of the Oronsay middens. Antiquity. 72, 178-184.

Roksandic, Z., Minagawa, M., Akazawa, T., 1988. Comparative analysis of dietary habits between Jomon and Ainu hunter-gatherers from stable carbon isotopes of human bone. J. Anthrop. Soc. Nippon. 96, 391-404.

Schoeninger, M.J., DeNiro, M.J., 1984. Nitrogen and carbon isotopic composition of bone collagen from marine and terrestrial animals. Geochim. Cosmochim. Acta. $48,625-639$.

Schoeninger, M.J., DeNiro, M.J., Tauber, H., 1983. Stable nitrogen isotope ratios of bone collagen reflect marine and terrestrial components of prehistoric human diet. Science. 220, 1381-1383.

Schulting, R.J., Blockley, S.M., Bocherens, H., Drucker, D., Richards, M., 2008. Stable carbon and nitrogen isotope analysis on human remains from the Early Mesolithic site of La Vergne (Charente-Maritime, France). J. Archaeol. Sci. 35, $763-772$.

Schulting, R.J., Richards, M.P., 2001. Dating women and becoming farmers: new palaeodietary and AMS dating evidence from the Breton Mesolithic cemeteries of Téviec and Hoëdic. J. Anthrop. Archaeol. 20, 314-344.

Sealy, J., 2006. Diet, mobility, and settlement pattern among holocene hunter-gatherers in southernmost Africa. Curr. Anthrop. 47, 569-595.

Sealy, J.C., van der Merwe, N.J., 1985. Isotope assessment of Holocene human diets in 
Journal of Archaeological Science, 37 (2010) 1968-1977

the southwestern Cape, South Africa. Nature. 315, 138-140.

Shiomi, H., Kawagoshi, T., Kawase, M., 1971. Report on the excavation of Ota shell mound of the Onomichi city, Hiroshima prefecture, in: Shiomi, H. (Ed.), Report on the Research of Cultural Heritage of Hiroshima Prefecture, 9. Educational Board of Hiroshima Prefecture, Hiroshima (in Japanese).

Stenhouse, M.J., Baxter, M.S., 1979. The uptake of bomb 14C in humans, in: Berkeley, R., Suess, H. (Eds.), Radiocarbon Dating. University of California Press, pp. $324-341$.

Tauber, H., 1983. ${ }^{13} \mathrm{C}$ evidence for dietary habits of prehistoric man in Denmark, Nature. 292, 332-333.

Temple, D.H., 2007. Dietary variation and stress among prehistoric Jomon foragers from Japan. Amer. J. Phys. Anthrop. 133, 1035-1046.

Temple, D.H., 2008. What can variation in stature reveal about environmental differences between prehistoric Jomon foragers? Understanding the impact of systemic stress on developmental stability. Amer. J. Hum. Biol. 20, 431-439.

Tieszen, L.L., Fagre, T., 1993. Effect of diet quality and composition on the isotopic composition of respiratory $\mathrm{CO}_{2}$, bone collagen, bioapatite, and soft tissues, in: Lambert, J.B., Grupe, G. (Eds.), Prehistoric Human Bone-archaeology at the Molecular Level. Springer-Verlag, Berlin, pp. 121-155.

Toizumi, T., 2000. Prehistoric fishery in the final Jomon period around Atumi peninsula, central Japan. Zoo-archaeol. 14, 23-38 (in Japanese).

Toizumi, T., 2008. Animal remains (shellfish, bone), in: Japanese Archaeological Association (Ed.), Source Book of the Meeting of Japanese Archaeological Association, Aichi, 2008. Japanese Archaeological Association, Aichi, pp. 
Journal of Archaeological Science, 37 (2010) 1968-1977

69-76 (in Japanese).

Tsukada, M., 1986. Vegetation in prehistoric Japan: The last 20,000 years, in: Pearson, R.J. (Ed.), Windows on the Japanese Past: Studies in Archaeology and Prehistory. Center for Japanese Studies, The University of Michigan, Ann Arbor, MI, pp. 11-56.

Walker, P.L., DeNiro, M.J., 1986. Stable nitrogen and carbon isotope ratios in bone collagen as indices of prehistoric dietary dependence on marine and terrestrial resources in southern California. Amer. J. Phys. Anthrop. 71, 51-61.

Winterhalder, B., 1996. Social foraging and the behavioral ecology of intragroup resource transfers. Evol. Anthrop. 5, 46-57.

Yoneda, M., Hirota, M., Uchida, M., Tanaka, A., shibata, Y., Morita, M., Akazawa, T., 2002. Radiocarbon and stable isotope analyses on the earliest Jomon skeletons from the Tochibara rockshelter, Nagano, Japan, Radiocarb. 44, 549-557.

Yoneda, M., Suzuki, R., Shibata, Y., Morita, M., Sukegawa, T., Shigehara, N., Akazawa, T., 2004. Isotopic evidence of inland-water fishing by a Jomon population excavated from the Boji site, Nagano, Japan. J. Archaeol. Sci. 31, 97-107.

Yoneda, M., Yoshida, K., Yoshinaga, J., Morita, M., Akazawa, T., 1996. Reconstruction of paleodiet in Nagano Prefecture based on the carbon and nitrogen isotope analysis and the trace elemental analysis. Daiyonki-kenkyu (Quat. Res.). 35, 293-303 (in Japanese with English abstract).

Yorimitsu, K., 1935. Anthropological research on the skeletons of Kameyama shell mound, 1 Skull. J. Anthrop. Soc. Nippon. 50, 1-39. 
Journal of Archaeological Science, 37 (2010) 1968-1977

Table 1. Sites for stable isotope analysis.

\begin{tabular}{cccccc}
\hline Sites & N & District & Period & Dates & Ref. \\
\hline Ota & 25 & Sanyo & Middle & $5000-4000$ & Kawase, 2006 \\
Funamoto & 9 & Sanyo & Middle & $5000-4000$ & Kawase, 2006 \\
Tsukumo & 53 & Sanyo & Late to Final & $4000-2300$ & Kawase, 2006 \\
Kawaji & 9 & Tokai & Late & $3700-3300$ & Benimura, 1984 \\
Yoshigo & 38 & Tokai & Late to Final & $3500-2300$ & Benimura, 1984 \\
Inariyama & 29 & Tokai & Final & $2800-2500$ & Benimura, 1984 \\
\multicolumn{7}{l}{$\mathrm{N}=$ number of individuals for stable isotope analyses }
\end{tabular}


Journal of Archaeological Science, 37 (2010) 1968-1977

Table 2. Sample list and isotopic results for human skeletal remains.

\begin{tabular}{|c|c|c|c|c|c|c|c|}
\hline Site & $\begin{array}{c}\text { Sample } \\
\text { No. }\end{array}$ & Sex & Age & $\mathrm{Col} \%$ & $\mathrm{C} / \mathrm{N}$ & $\delta^{13} \mathrm{C}$ & $\delta^{15} \mathrm{~N}$ \\
\hline Ota & 664 & $\mathrm{~F}$ & Middle adult & 1.2 & 3.1 & -17.1 & 12.9 \\
\hline Ota & 665 & $\mathrm{~F}$ & Middle adult & 2.9 & 2.9 & -17.2 & 12.1 \\
\hline Ota & 666 & M & Middle adult & 2.5 & 3.2 & -17.1 & 12.3 \\
\hline Ota & 667 & M & Young adult & 2.1 & 3.3 & -17.2 & 12.7 \\
\hline Ota & 671 & M & Middle adult & 2.5 & 3.3 & -15.7 & 15.7 \\
\hline Ota & 674 & M & Young adult & 2.7 & 3.1 & -15.4 & 15.3 \\
\hline Ota & 681 & M & Middle adult & 2.7 & 3.1 & -15.4 & 14.4 \\
\hline Ota & 683 & M & Middle adult & 3.4 & 3.2 & -15.8 & 14.8 \\
\hline Ota & 684 & M & Young adult & 4.9 & 3.2 & -15.9 & 13.4 \\
\hline Ota & 685 & $\mathrm{~F}$ & Adolescent & 1.9 & 3.3 & -16.8 & 12.5 \\
\hline Ota & 686 & $\mathrm{~F}$ & Young adult & 3.7 & 3.2 & -19.3 & 8.7 \\
\hline Ota & 688 & $\mathrm{~F}$ & Young adult & 3.6 & 3.1 & -16.4 & 13.2 \\
\hline Ota & 693 & M & Young adult & 3.4 & 3.3 & -16.3 & 14.1 \\
\hline Ota & 694 & M & Adult & 3.6 & 3.3 & -15.6 & 13.4 \\
\hline Ota & 702 & M & Young adult & 5.6 & 3.3 & -16.2 & 14.1 \\
\hline Ota & 703 & M & Middle adult & 6.7 & 3.4 & -16.6 & 12.6 \\
\hline Ota & 710 & $\mathrm{~F}$ & Middle adult & 5.4 & 3.4 & -17.0 & 13.2 \\
\hline Ota & 711 & $\mathrm{~F}$ & Young adult & 4.0 & 3.4 & -17.0 & 13.0 \\
\hline Ota & 714 & M & Middle adult & 5.4 & 3.3 & -17.9 & 10.7 \\
\hline Ota & 717 & $\mathrm{~F}$ & Young adult & 3.9 & 3.3 & -16.3 & 12.9 \\
\hline Ota & 721 & M & Middle adult & 6.9 & 3.3 & -15.8 & 14.2 \\
\hline Ota & 722 & $\mathrm{~F}$ & Young adult & 1.8 & 3.3 & -16.4 & 14.0 \\
\hline Ota & 904 & $\mathrm{~F}$ & Adult & 2.6 & 3.3 & -19.6 & 7.7 \\
\hline Ota & 905 & $\mathrm{~F}$ & Young adult & 1.4 & 3.3 & -17.1 & 11.1 \\
\hline Ota & $708 \mathrm{~A}$ & M & Middle adult & 8.9 & 3.4 & -15.9 & 14.0 \\
\hline Funamoto & 100 & $\mathrm{~F} ?$ & Unknown & 1.8 & 3.3 & -17.9 & 11.6 \\
\hline Funamoto & 101 & $\mathrm{~F} ?$ & Adult & 1.8 & 3.3 & -16.4 & 12.8 \\
\hline Funamoto & 104 & Unknown & Unknown & 1.4 & 3.5 & -16.3 & 13.9 \\
\hline Funamoto & 105 & F & Young adult & 1.5 & 3.3 & -15.6 & 13.9 \\
\hline Funamoto & 106 & $\mathrm{~F}$ & Middle adult & 2.3 & 3.3 & -15.8 & 14.7 \\
\hline Funamoto & 107 & $\mathrm{~F}$ & Young adult & 2.5 & 3.3 & -16.0 & 13.9 \\
\hline Funamoto & 108 & $\mathrm{~F}$ & Young adult & 1.4 & 3.4 & -15.8 & 13.5 \\
\hline Funamoto & 112 & $\mathrm{~F}$ ? & Unknown & 2.3 & 3.3 & -14.8 & 14.9 \\
\hline Funamoto & 147 & $\mathrm{~F}$ & Unknown & 1.2 & 3.4 & -15.4 & 15.4 \\
\hline Tsukumo & 1 & $\mathrm{~F}$ & Middle adult & 1.7 & 3.3 & -15.3 & 13.9 \\
\hline Tsukumo & 2 & M & Young adult & 1.7 & 3.4 & -16.4 & 11.9 \\
\hline
\end{tabular}


Journal of Archaeological Science, 37 (2010) 1968-1977

\begin{tabular}{|c|c|c|c|c|c|c|c|}
\hline Tsukumo & 3 & M & Young adult & 1.7 & 3.3 & -16.4 & 12.3 \\
\hline Tsukumo & 4 & $\mathrm{~F}$ & Young adult & 2.7 & 3.3 & -15.4 & 13.6 \\
\hline Tsukumo & 5 & $\mathrm{M}$ & Young adult & 2.4 & 3.3 & -15.7 & 13.0 \\
\hline Tsukumo & 6 & $\mathrm{~F}$ & Young adult & 1.9 & 3.3 & -16.3 & 12.3 \\
\hline Tsukumo & 7 & $\mathrm{~F}$ & Young adult & 3.5 & 3.3 & -16.3 & 12.5 \\
\hline Tsukumo & 8 & $\mathrm{M}$ & Adolescent & 2.7 & 3.3 & -14.5 & 15.0 \\
\hline Tsukumo & 9 & $\mathrm{M}$ & Young adult & 1.9 & 3.3 & -15.7 & 13.1 \\
\hline Tsukumo & 10 & $\mathrm{M}$ & Middle adult & 1.0 & 3.6 & -16.5 & 12.8 \\
\hline Tsukumo & 11 & $\mathrm{~F}$ & Young adult & 1.9 & 3.3 & -15.4 & 13.9 \\
\hline Tsukumo & 12 & $\mathrm{~F}$ & Adolescent & 3.1 & 3.2 & -16.1 & 12.5 \\
\hline Tsukumo & 13 & M & Middle adult & 2.2 & 3.3 & -17.9 & 10.2 \\
\hline Tsukumo & 14 & $\mathrm{~F}$ & Young adult & 2.3 & 3.4 & -19.5 & 7.6 \\
\hline Tsukumo & 16 & $\mathrm{~F}$ & Young adult & 2.0 & 3.4 & -16.2 & 12.5 \\
\hline Tsukumo & 17 & $\mathrm{~F}$ & Old adult & 2.3 & 3.3 & -14.6 & 14.9 \\
\hline Tsukumo & 19 & $\mathrm{M}$ & Young adult & 1.7 & 3.4 & -16.0 & 12.8 \\
\hline Tsukumo & 20 & $\mathrm{~F}$ & Young adult & 2.6 & 3.3 & -18.1 & 10.9 \\
\hline Tsukumo & 23 & $\mathrm{~F}$ & Young adult & 3.0 & 3.3 & -15.6 & 13.3 \\
\hline Tsukumo & 24 & M & Young adult & 2.1 & 3.3 & -16.2 & 12.6 \\
\hline Tsukumo & 25 & Unknown & Child & 2.6 & 3.3 & -19.7 & 6.6 \\
\hline Tsukumo & 27 & M & Middle adult & 2.7 & 3.3 & -15.5 & 13.3 \\
\hline Tsukumo & 29 & $\mathrm{~F}$ & Adolescent & 1.7 & 3.3 & -14.6 & 14.4 \\
\hline Tsukumo & 30 & M & Young adult & 1.9 & 3.3 & -15.2 & 11.7 \\
\hline Tsukumo & 32 & M & Young adult & 2.3 & 3.3 & -16.2 & 12.4 \\
\hline Tsukumo & 33 & M & Middle adult & 1.8 & 3.4 & -15.7 & 13.4 \\
\hline Tsukumo & 34 & $\mathrm{~F}$ & Young adult & 1.2 & 3.4 & -16.1 & 13.0 \\
\hline Tsukumo & 35 & M & Young adult & 1.6 & 3.5 & -16.4 & 13.3 \\
\hline Tsukumo & 36 & $\mathrm{M}$ & Middle adult & 1.9 & 3.4 & -16.5 & 12.8 \\
\hline Tsukumo & 37 & $\mathrm{~F}$ & Middle adult & 1.9 & 3.3 & -15.7 & 12.9 \\
\hline Tsukumo & 38 & $\mathrm{~F}$ & Old adult & 1.9 & 3.3 & -15.5 & 13.1 \\
\hline Tsukumo & 39 & M & Young adult & 3.8 & 3.3 & -19.6 & 5.4 \\
\hline Tsukumo & 40 & $\mathrm{~F}$ & Old adult & 1.1 & 3.4 & -19.1 & 8.1 \\
\hline Tsukumo & 41 & $\mathrm{~F}$ & Old adult & 1.9 & 3.3 & -16.0 & 12.8 \\
\hline Tsukumo & 42 & $\mathrm{~F}$ & Young adult & 1.8 & 3.4 & -16.3 & 13.0 \\
\hline Tsukumo & 43 & M & Middle adult & 2.0 & 3.4 & -15.3 & 14.8 \\
\hline Tsukumo & 44 & $\mathrm{~F}$ & Young adult & 1.7 & 3.4 & -19.1 & 9.1 \\
\hline Tsukumo & 46 & M & Middle adult & 1.3 & 3.3 & -17.4 & 12.5 \\
\hline Tsukumo & 55 & M & Young adult & 1.5 & 3.3 & -15.6 & 12.3 \\
\hline Tsukumo & 58 & M & Middle adult & 1.6 & 3.4 & -15.3 & 14.9 \\
\hline Tsukumo & 59 & $\mathrm{~F}$ & Young adult & 2.2 & 3.3 & -15.1 & 14.4 \\
\hline
\end{tabular}


Journal of Archaeological Science, 37 (2010) 1968-1977

\begin{tabular}{cccccccc} 
Tsukumo & 60 & $\mathrm{~F}$ & Young adult & 3.7 & 3.2 & -17.6 & 11.4 \\
Tsukumo & 61 & $\mathrm{M}$ & Young adult & 1.4 & 3.3 & -16.4 & 13.0 \\
Tsukumo & 62 & $\mathrm{~F}$ & Young adult & 3.1 & 3.2 & -17.6 & 10.2 \\
Tsukumo & 63 & Unknown & Unknown & 2.8 & 3.3 & -17.4 & 10.7 \\
Tsukumo & 65 & $\mathrm{M}$ & Young adult & 2.8 & 3.3 & -17.8 & 10.0 \\
Tsukumo & 66 & $\mathrm{M}$ & Young adult & 2.1 & 3.3 & -17.1 & 11.0 \\
Tsukumo & 67 & $\mathrm{~F}$ & Middle adult & 2.9 & 3.3 & -17.4 & 11.0 \\
Tsukumo & 68 & $\mathrm{~F}$ & Young adult & 2.8 & 3.3 & -17.3 & 10.9 \\
Tsukumo & 70 & $\mathrm{~F}$ & Young adult & 2.4 & 3.3 & -15.6 & 13.0 \\
Tsukumo & 151 & $\mathrm{M}$ & Middle adult & 1.1 & 3.5 & -16.0 & 14.0 \\
Tsukumo & 164 & $\mathrm{~F}$ & Young adult & 2.2 & 3.4 & -17.1 & 12.1 \\
Tsukumo & $162 \mathrm{~A}$ & $\mathrm{~F}$ & Middle adult & 1.4 & 3.3 & -16.4 & 12.4 \\
Kawaji & 166 & $\mathrm{~F}$ & Middle adult & 2.1 & 3.3 & -14.3 & 10.6 \\
Kawaji & 172 & $\mathrm{~F}$ & Young adult & 0.9 & 3.5 & -17.2 & 11.0 \\
Kawaji & 173 & $\mathrm{~F}$ & $?$ & 0.7 & 3.3 & -15.9 & 11.4 \\
Kawaji & 174 & $\mathrm{~F} ?$ & $?$ & 1.0 & 3.3 & -14.4 & 13.8 \\
Kawaji & 175 & $\mathrm{M}$ & Young adult? & 0.9 & 3.3 & -15.5 & 12.2 \\
Kawaji & 179 & $\mathrm{~F}$ & Young adult & 0.9 & 3.4 & -14.3 & 13.5 \\
Kawaji & 180 & $\mathrm{M}$ & $?$ & 0.9 & 3.6 & -13.9 & 13.8 \\
Kawaji & 181 & $\mathrm{~F}$ & Middle adult & 1.4 & 3.3 & -14.8 & 12.3 \\
Kawaji & 182 & $\mathrm{M} ?$ & Middle adult & 1.5 & 3.3 & -14.4 & 13.5 \\
Inariyama & 210 & $\mathrm{Unknown}$ & Adolescent & 1.9 & 3.4 & -17.6 & 8.8 \\
\hline
\end{tabular}


Journal of Archaeological Science, 37 (2010) 1968-1977

Table 3. Sample list and isotopic results for faunal skeletal remains.

\begin{tabular}{cccccccc}
\hline $\begin{array}{c}\text { Sample } \\
\text { No. }\end{array}$ & Species & Specific name & Site & Col\% & C/N & $\delta^{13} \mathrm{C}$ & $\delta^{15} \mathrm{~N}$ \\
\hline T68DA & Deer & Cervus nippon & Tsukumo & 3.0 & 3.5 & -22.6 & 5.0 \\
T68DB & Deer & Cervus nippon & Tsukumo & 5.1 & 3.3 & -21.7 & 4.5 \\
T59D & Deer & Cervus nippon & Tsukumo & 5.7 & 3.2 & -20.9 & 4.7 \\
T67D & Deer & Cervus nippon & Tsukumo & 6.4 & 3.2 & -20.9 & 4.1 \\
O680D & Deer & Cervus nippon & Ota & 1.1 & 3.5 & -22.8 & 5.2 \\
TS102D & Deer & Cervus nippon & Funamoto & 3.9 & 3.3 & -19.1 & 5.4 \\
T70B & Boar & Sus scrofa & Tsukumo & 4.9 & 3.4 & -19.1 & 7.5 \\
T59B & Boar & Sus scrofa & Tsukumo & 6.4 & 3.4 & -20.9 & 5.1 \\
T2B & Boar & Sus scrofa & Tsukumo & 4.3 & 3.5 & -19.7 & 5.0 \\
T39B & Boar & Sus scrofa & Tsukumo & 4.5 & 3.4 & -20.7 & 6.4 \\
T2FA & Red sea bream & Pagrinae & Tsukumo & 6.2 & 3.3 & -12.0 & 13.5 \\
T2FB & Red sea bream & Pagrinae & Tsukumo & 3.0 & 3.5 & -12.7 & 13.8 \\
T2FC & Red sea bream & Pagrinae & Tsukumo & 3.2 & 3.3 & -11.8 & 13.8 \\
T2FD & Red sea bream & Pagrinae & Tsukumo & 3.9 & 3.3 & -12.0 & 14.3 \\
T2FE & Red sea bream & Pagrinae & Tsukumo & 3.3 & 3.3 & -11.8 & 13.6 \\
T2FF & Red sea bream & Pagrinae & Tsukumo & 2.5 & 3.3 & -9.7 & 11.9 \\
T2FG & Red sea bream & Pagrinae & Tsukumo & 4.1 & 3.3 & -11.6 & 12.6 \\
T2FH & Red sea bream & Pagrinae & Tsukumo & 4.8 & 3.4 & -12.4 & 13.7 \\
\hline
\end{tabular}


Journal of Archaeological Science, 37 (2010) 1968-1977

Table 4. Summary of stable isotope analysis for human and faunal skeletal remains.

\begin{tabular}{ccccccc}
\hline \multirow{2}{*}{ Species } & Sites & $\mathrm{N}$ & \multicolumn{2}{c}{$\delta^{13} \mathrm{C}(\% \mathrm{o})$} & \multicolumn{2}{c}{$\delta^{15} \mathrm{~N}(\% \mathrm{o})$} \\
\cline { 3 - 6 } & & & Mean & $\mathrm{SD}$ & Mean & $\mathrm{SD}$ \\
\hline Human & Ota & 25 & -16.7 & 1.1 & 12.9 & 1.8 \\
& Funamoto & 9 & -16.0 & 0.9 & 13.8 & 1.1 \\
& Tsukumo & 53 & -16.5 & 1.3 & 12.2 & 2.0 \\
& Kawaji & 9 & -15.0 & 1.0 & 12.5 & 1.2 \\
& Yoshigo & 38 & -16.3 & 1.7 & 10.8 & 1.9 \\
& Inariyama & 29 & -16.7 & 1.4 & 9.7 & 1.2 \\
Deer & & & & & & \\
Boar & Sanyo & 6 & -21.3 & 1.4 & 4.8 & 0.5 \\
Red sea bream & Tsukumo & 4 & -20.1 & 0.8 & 6.0 & 1.2 \\
& Tsukumo & 8 & -11.7 & 0.9 & 13.4 & 0.8 \\
\hline
\end{tabular}


Journal of Archaeological Science, 37 (2010) 1968-1977

Table 5. Stable isotope ratios of estimated protein sources.

\begin{tabular}{|c|c|c|c|c|c|}
\hline \multirow[t]{2}{*}{ Protein sources } & \multicolumn{2}{|c|}{$\delta^{13} \mathrm{C}(\%)$} & \multicolumn{2}{|c|}{$\delta^{15} \mathrm{~N}(\%)$} & \multirow[t]{2}{*}{ Ref. } \\
\hline & Mean & SD & Mean & SD & \\
\hline $\mathrm{C}_{3}$ plants & -20.9 & 1.6 & 4.6 & 2.4 & Yoneda et al., 2004 \\
\hline Terrestrial mammals & -19.8 & 1.3 & 8.7 & 1.0 & This study \\
\hline Freshwater fish & -19.0 & 0.9 & 12.0 & 1.9 & Yoneda et al., 2004 \\
\hline Marine fish & -10.7 & 0.9 & 16.8 & 0.8 & This study \\
\hline Marine shellfish & -9.8 & 1.6 & 11.7 & 2.1 & Yoneda et al., 2004 \\
\hline
\end{tabular}




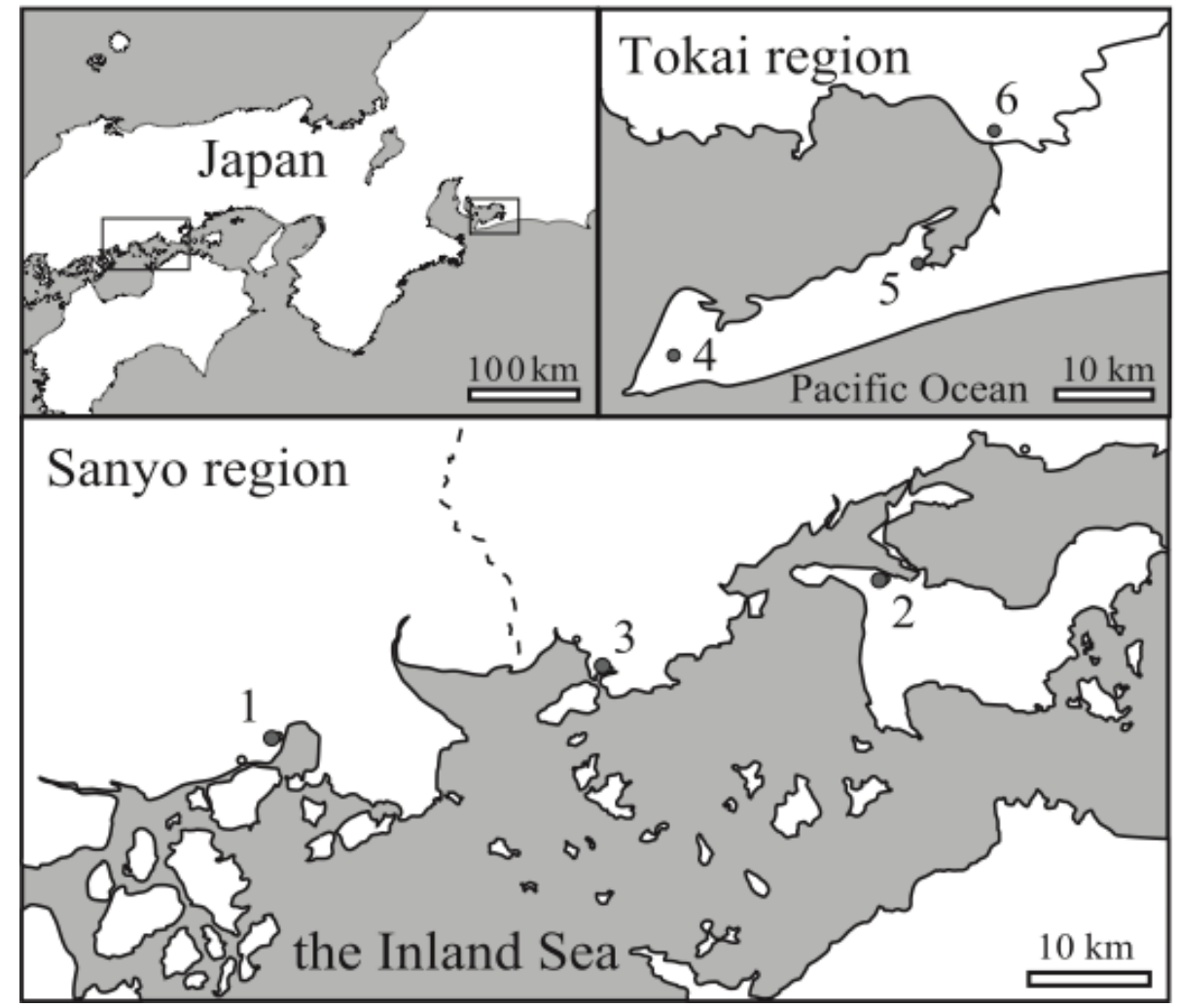

Fig. 1: Plan map of study area in the Sanyo and Tokai regions, Japan, showing the location of the sites. Numbered gray circles are locations of the shell mounds: 1, Ota; 2, Funamoto; 3, Tsukumo; 4, Kawaji; 5,Yoshigo; 6, Inariyama. 
Journal of Archaeological Science, 37 (2010) 1968-1977

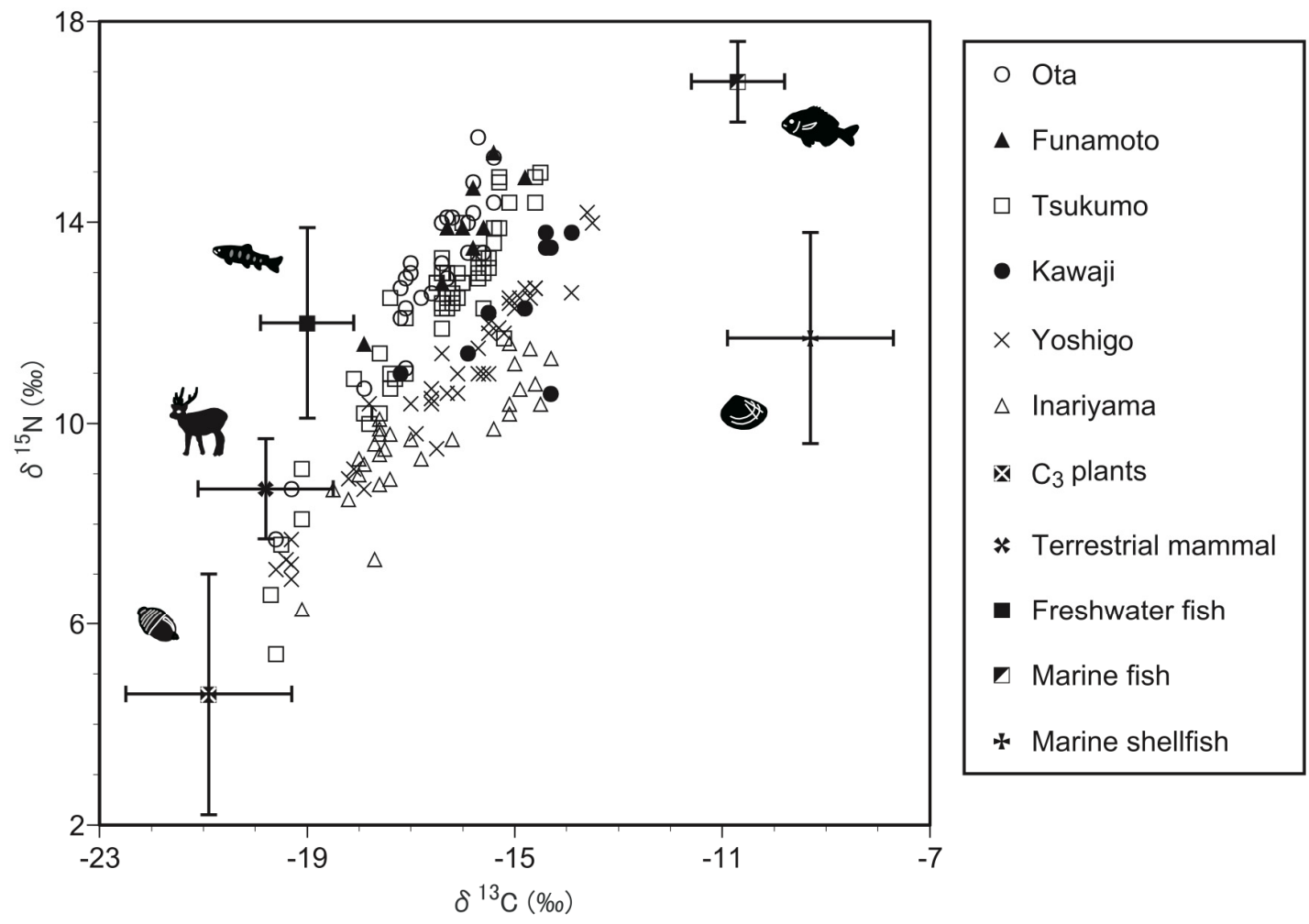

Fig. 2: Human carbon and nitrogen isotopic values compared with the isotopic values of protein sources. The mean isotopic values of protein sources are presented with error bars of one standard deviation. 
Journal of Archaeological Science, 37 (2010) 1968-1977

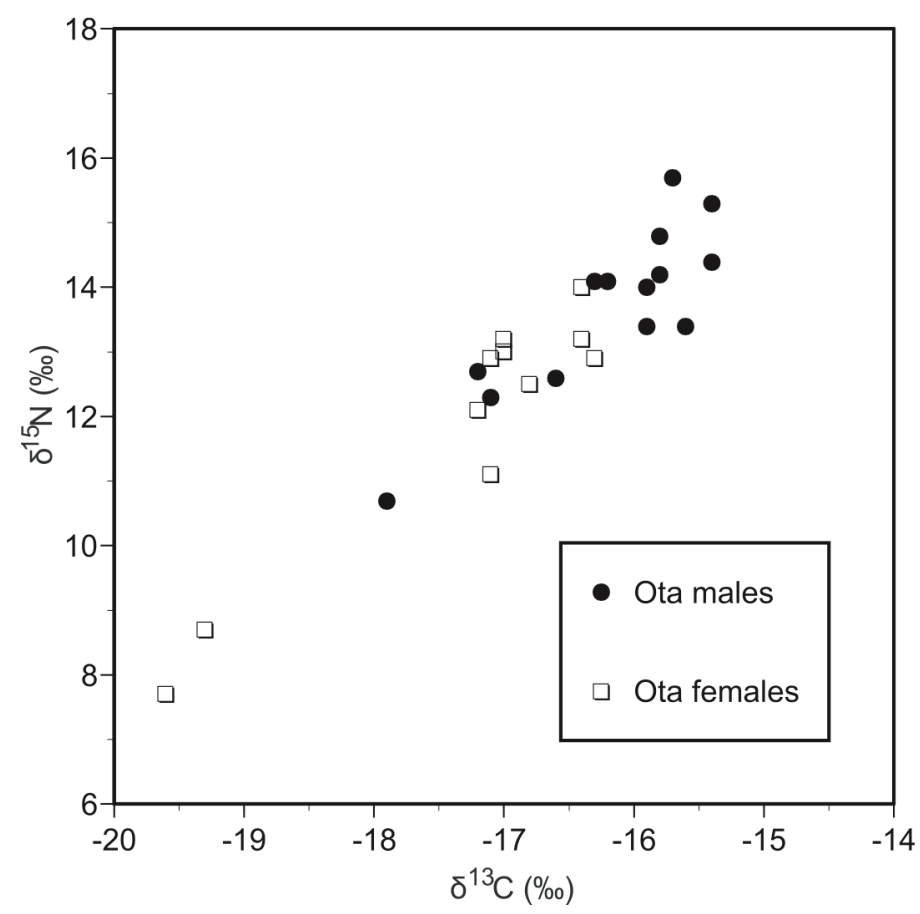

Fig. 3: Carbon and nitrogen isotopic values for the Ota population according to sex. 
Journal of Archaeological Science, 37 (2010) 1968-1977
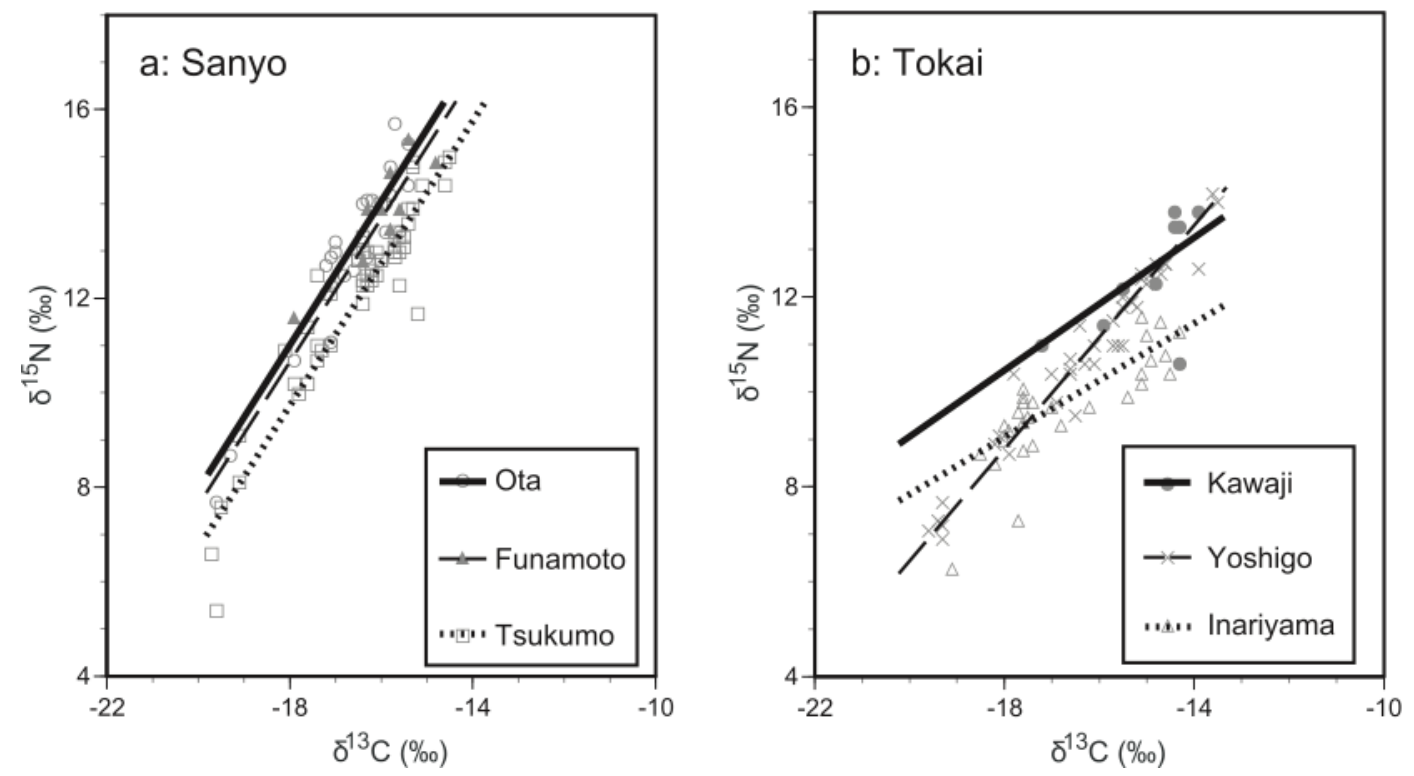

Fig. 4: (a) Regression lines of isotopic data of the Sanyo samples; (b) Regression lines of isotopic data of the Tokai samples. 